\title{
Effects of freezing-thawing on the spermatozoon nucleus: a comparative chromatin cytophotometric study in the porcine and human species
}

\author{
S Hamamah 1*, D Royère 1, JC Nicolle 2, M Paquignon 3, \\ $\mathrm{J}$ Lansac 1 \\ 1 Unité de Reproduction, Département de Gynécologie-Obstétrique, Hôpital Bretonneau, \\ 37044 Tours, Cedex; \\ 2 INRA, Physiologie de la Reproduction, Nouzilly; \\ 3 ITP, MNE, Paris, France
}

(Received 21 October 1988; accepted 23 October 1989)

\begin{abstract}
Summary - Freezing-thawing effects on the nuclei of porcine and human spermatozoa were studied by determining native DNA percentage from fluorescence after acridine orange (AO) staining and by analyzing chromatin structure by a quantitative microspectrophotometric study of FeulgenDNA complexes before and after freezing. The study of boar spermatozoa revealed no alteration in native DNA percentage after freezing. However, native DNA percentage decreased significantly in human spermatozoa. Feulgen-DNA content and sperm nuclear surface area decreased in both species after freezing. These results prompted us to hypothesize an overcondensation of sperm chromatin after freezing-thawing. This overcondensation may be related to the lower conception rates obtained with human and porcine semen after cryostorage via defective decondensation.
\end{abstract}

freezing-thawing / spermatozoon / chromatin / acridine orange / Feulgen-DNA / boar / man

Résumé - Effet de la congélation sur le noyau des spermatozoïdes : Etude cytophotométrique comparative entre le verrat et l'homme. L'effet de la congélation sur le noyau des spermatozoïdes a été étudié en déterminant le taux d'ADN natif, en microscopie à fluorescence, par le marquage à l'Acridine Orange et en analysant la structure de la chromatine par l'étude microspectrophotométrique quantitative de l'ADN-Feulgen, avant et après congélation de spermatozoïdes porcins et humains. L'étude réalisée chez le verrat ne montre pas d'altération du taux d'ADN natif après congélation. En revanche ce taux est significativement diminué dans les mêmes conditions chez l'homme. En outre pour ces 2 espèces, nous avons observé une réduction significative des complexes ADN-Feulgen après congélation, qui s'accompagne également d'une diminution de la surface des noyaux des spermatozoïdes. Ces résultats évoquent une compaction ou "surcondensation" des noyaux au-delà de l'état de condensation acquis en fin de maturation épididymaire. Le taux d'ADN natif semble, chez l'homme, apporter une information complémentaire sur l'appréciation du pouvoir fécondant du sperme avant et après congélation. Chez le verrat comme chez l'homme, l'état de "surcondensation" nucléaire provoqué par la congélation pourrait, en retardant la décondensation du pronucleus paternel, expliquer en partie la diminution du taux de conception lors d'insémination avec sperme congelé.

congélation / spermatozö̈de / chromatine / acridine orange / ADN-Feulgen / verrat / homme

* Correspondence and reprints 


\section{INTRODUCTION}

Several studies have shown that the fertilizing ability of human and porcine spermatozoa is reduced by cryostorage (boar: Paquignon et al, 1980; Johnson, 1985; ma: Schwartz and Heuchel, 1982). This decrease is possibly due to changes in the structure of the acrosomal, plasma membranes and/or flagellum (boar: Paquignon, 1984; Johnson, 1985; Courtens and $\mathrm{Pa}$ quignon, 1985; man: Pedersen and Lebech, 1971; Escalier and Bisson, 1980; Mahadevan and Trounson, 1984; Oettle and Soley, 1986). However, the possibility that the reduced fertilizing ability of cryostored sperm might also be associated with nuclear abnormalities has not been investigated. The purpose of the present study was to compare the effects of freezing-thawing on porcine and human chromatin of spermatozoa nuclei using acridine orange (AO) staining and quantitative Feulgen-DNA measurement. Results concerning the nuclear state of human spermatozoa have been partly reported elsewhere (Royère et al, 1988).

\section{MATERIALS AND METHODS}

Ejaculates were collected from 8 adult LargeWhite boars and from 10 men participating in our IVF programme. Half of each ejaculate was processed as described by Paquignon et al (1980) and by Behrman and Ackerman (1969) for boar and man respectively. Fresh and frozen semen from each ejaculate was washed twice by centrifugation with PBS, $\mathrm{pH} 7.3(300 \mathrm{~g}, 10$ $\mathrm{min}$ ) and adjusted to $50 \times 10^{6}$ spermatozoa $/ \mathrm{ml}$ in PBS. Spermatozoa were smeared on slides and fixed in methanol/glacial acetic acid $(3 / 1$, $\mathrm{v} / \mathrm{v})$. The $A O$ staining was carried out according to Tejada et al (1984). Slides were observed on an epifluorescence microscope using a $490 \mathrm{~nm}$ excitation filter and a 530-nm barrier filter. 300 400 spermatozoa were observed on each slide and divided into green and orange/red spermatozoon heads.
Feulgen-DNA content was determined after Schiff-Feulgen staining. The Feulgen-DNA content and the surface area of the spermatozoon head were measured simultaneously, using a scanning method (Esnault and Nicolle, 1976) with an automatic microspectrophotometer (UMSP1 Zeiss). To avoid errors due to experimental technique, fresh and frozen sperm were treated together during the various stages of Feulgen staining. Feulgen-DNA and nuclear surface were measured in 4 of the 8 boars and in all of the men.

AO staining was expressed as the ratio of the spermatozoon heads, which stained green (native DNA: double-helix), to the total count. Feulgen-stained DNA content was expressed in arbitrary units (AU) as the mean extinction ( \pm SEM) for 30 and 15 morphologically normal spermatozoa for each sample of boar and human semen, respectively. Freezing-thawing effects on native DNA percentage and Feulgen-DNA content were analyzed using the Wilcoxon paired signed-rank test (Siegel, 1956).

\section{RESULTS}

\section{Freezing-thawing effects on the native DNA percentage of spermatozoa}

The native DNA percentage of fresh and frozen ejaculated boar spermatozoa was high (>90\%). It showed relatively low interindividual variability with $89-96 \%$ of the nuclei showing green fluorescence, indicative of the presence of the DNA in its native state in most sperm cells. After freezing, these values did not change significantly (fig 1a). Thus in the boar, freezing-thawing did not affect the spermatozoon DNA state.

In humans, as opposed to boar spermatozoa, the mean native DNA percentage of fresh ejaculated spermatozoa was lower $(44.65 \%)$ and varied considerably between individuals (26-64\%). Moreover, a significant decrease $(\approx 10 \%)$ in mean na- 
tive DNA percentage was observed after freezing-thawing ( $P<0.02$; fig $1 b)$.

In contrast with the high human interindividual variability, we observed no significant intraindividual variation between 2 ejaculates of the same subjects in boars as in men : mean difference $1.5(P=0.27)$, and $0.81(P=0.49)$, respectively.

\section{Freezing-thawing effects on the structure of chromatin}

Four boars were selected for the FeulgenDNA study, as their sperm presented the greater decrease in native DNA percent-
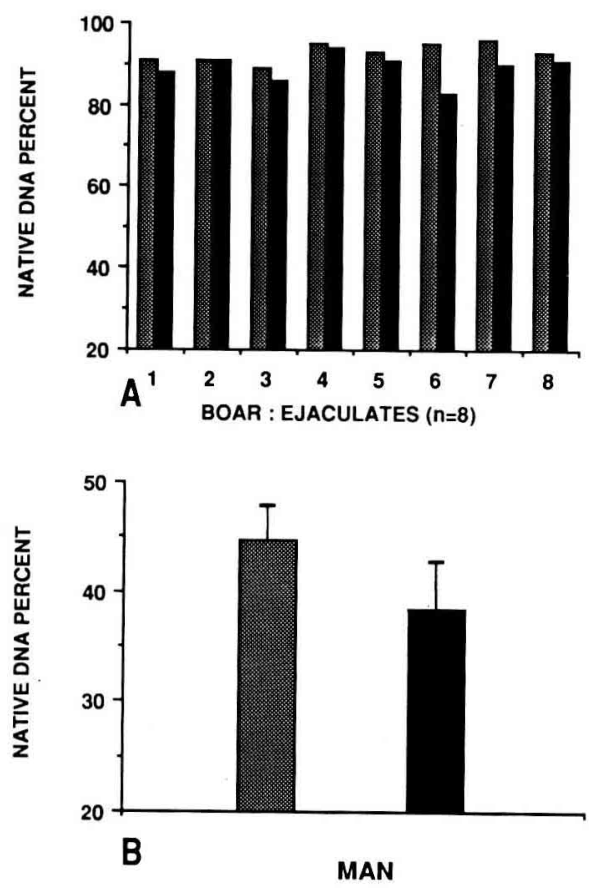

Fig 1. Freezing-thawing effects on native DNA percent in spermatozoa from 8 boars and 10 men. Results are represented before (国) and after (D) freezing-thawing for boars (A) as individual values (400 spermatozoa/ejaculate), for men $(B)$ as mean $( \pm$ SEM). (1 ejaculate/subject). age after freezing-thawing. The FeulgenDNA content of boar spermatozoa, except in 1 animal, decreased after freezingthawing $(-23,-7.2,+1.3$ and $-14.7 \%$, respectively; fig 2a). Under the same conditions, a reduction was observed in the nuclear surface area of the sperm heads $(-4,-1,-1$ and $-5 \%$, respectively; fig 2c).

The effects of freezing on the chromatin of human spermatozoa were similar to those observed in the boars. Frozen spermatozoa showed a significant reduction $(10 \%)$ of mean Feulgen-DNA content $(P<$ 0.001 ; fig $2 b)$ as the surface of the spermatozoa nuclei decreased $(6 \%, P<0.01$; fig 2d).

No relationship was observed between Feulgen-DNA content and nuclear surface, nor any relationship between these 2 parameters and human in vitro fertilization rate.

\section{DISCUSSION}

Freezing-thawing effects on the nuclei of boar and human spermatozoa were studied using acridine orange staining and microspectrophotometric Feulgen-DNA measurements. Acridine orange, a fluorochrome stain which binds to doublestranded DNA and shows green fluorescence, also binds to single-stranded DNA causing a red fluorescence (Stockert and Lisanti, 1972). Whatever the population of spermatozoa (homogenous in the boar or heterogenous in man), the evaluation of abnormal chromatin by $A O$ staining revealed the existence of spontaneous DNA denaturation in ejaculated semen. This denaturation was greater in man than in the boar. Moreover, the single-stranded DNA percentage increased in human spermatozoa after freezing and thawing. In our study, the percentage of spontaneously 

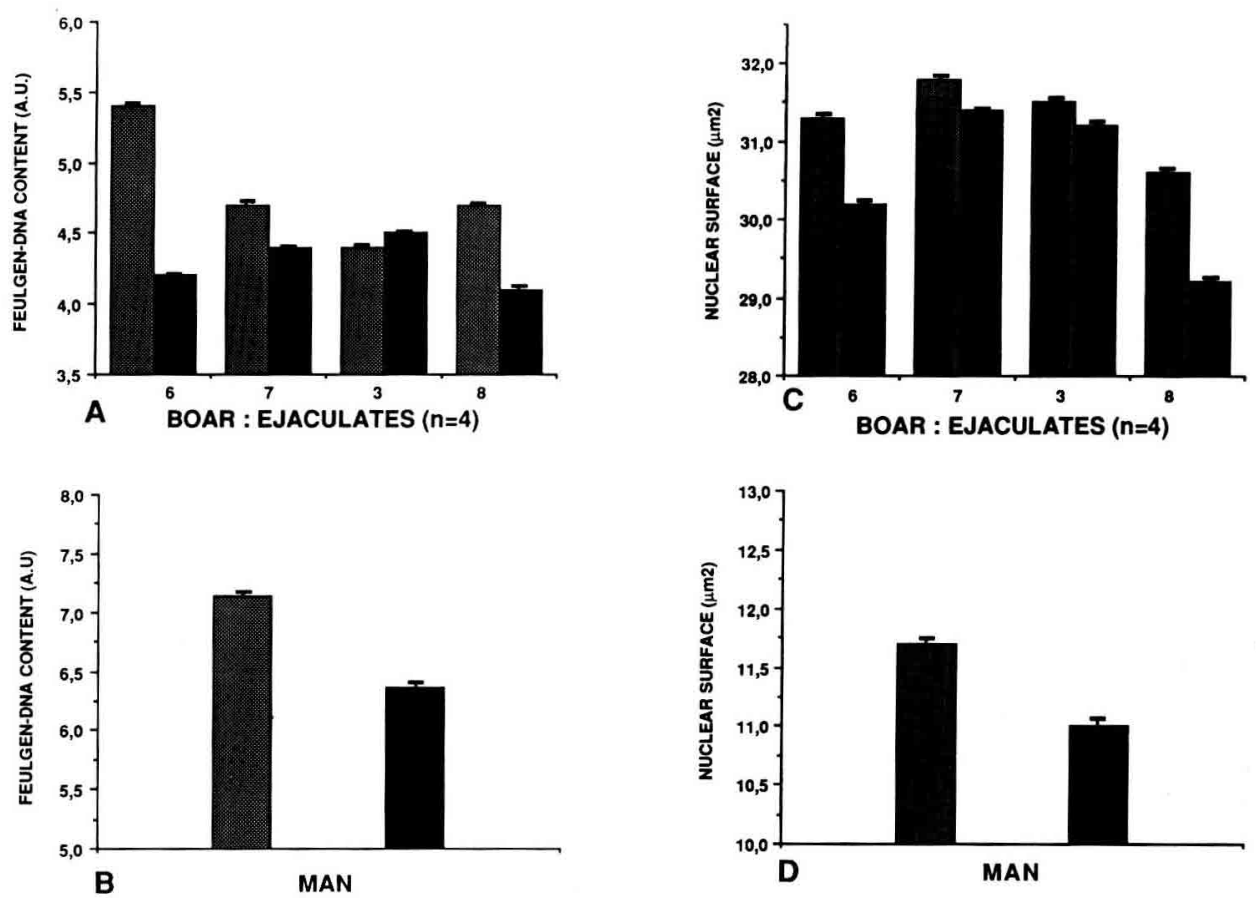

Fig 2. Freezing-thawing effects on spermatozoa Feulgen-DNA content $(A=$ boars; $B=$ men) and mean nuclear surface $(C=$ boars; $D=$ men). Values are represented before $($ O $)$ and after $(\square)$ freezingthawing as individual values for boars, as mean ( \pm SEM) for men. Individual results were expressed as a mean ( \pm SEM) between 30 spermatozoa (boars). Same No for ejaculates as in fig 1.

denatured DNA observed in the boar was lower than in the bull and the mouse (Evenson et al, 1980), contrasting with the higher denaturation rates for man (Tejada et al, 1984; Royère et al, 1988). It is important to notice that in our study, we observed in the 2 species a low intraindividual variability, in spite of the great interindividual variability found only in human spermatozoa. Such results allow us to consider native DNA as a reliable parameter for each subject. Similarly, $A O$ staining revealed no freezing effects on native DNA percentage of boar spermatozoon nuclei, contrasting with the decrease of native DNA percentage after freezing in man, indicating that, in this species, staining with $\mathrm{AO}$ should provide another parameter for estimating the quality of frozen spermatozoa. Tejada et al (1984) and Botes (1987) have already suggested native DNA percentage as an additional parameter of fertilizing ability of human spermatozoa. Furthermore, it would be of interest to determine spermatozoon nucleus quality in infertile subjects with apparently normal sperm.

In this study, the decrease of FeulgenDNA content and nuclear surface area observed in boar as in man after freezingthawing, argues for modified relationships 
between DNA and nucleoproteins. Combined, these results suggest that spermatozoon chromatin might reach a degree of condensation greater than that which normally occurs at the end of epididymal maturation. Such chromatin alterations were observed during spermateliosis and epididymal maturation in the bull (Gledhill, 1971) and in the ram (Esnault and Nicolle, 1976) as well as in vitro under the effects of uterine secretions on ram corpus epididymal spermatozoa (Nicolle et al, 1985). Similar effects of freezing and thawing on spermatozoon chromatin have been described qualitatively in boar (Courtens and Paquignon, 1985) and quantitatively in man (Royère et al, 1988).

Variation in the stability of spermatozoon chromatin after freezing suggests that chromatin undergoes important changes which might involve variation, during the freezing-thawing procedure, in the content of elements such as zinc, known to be involved in chromatin condensation (man: Kvist et al, 1988).

Finally, it seems that the modifications in spermatozoon nuclei caused by freezing-thawing might result in defective decondensation of the nucleus during fertilization, leading to a delay in the formation of the male pronucleus and/or the first division events. One consequence of this might be early embryonic mortality or lower embryonic development, observed after artificial insemination with frozen spermatozoa (boar: Lwoff et al, 1987; man: Schwartz et al, 1983).

\section{ACKNOWLEDGMENTS}

We would like to thank $\mathrm{Dr} U$ Kvist and $\mathrm{Dr} \mathrm{JL}$ Courtens for their very helpful comments on the manuscript, Dr A Mills for his help in the English translation, and Miss I Berdrin for the preparation of this manuscript. This research was supported in part by the Institut National de la Re- cherche Agronomique (cryobiologie, INRA 1247 A).

\section{REFERENCES}

Behrman SJ, Ackerman DR (1969) Freeze preservation of human semen. Am J Obstet 103, 654-658

Botes ADE (1987) The effective sperm count correlated with fertilization in vitro. 5th World Congress on IVF and ET. Norfolk, abstr, p 95

Courtens $\mathrm{JL}$, Paquignon $M$ (1985) Ultrastructure of fresh frozen and frozen-thawed spermatozoa of boar. In: Deep Freezing of Boar Semen (Johnson LA, Larsson K, eds), University of Agriculture Sciences, Uppsala, Sweden, 61-87

Escalier D, Bisson JP (1980) Quantitative ultrastructural modifications in human spermatozoa after freezing. In: Human Artificial Insemination and Semen Preservation (David G, Price WS, eds), Plenum Press, NY, 107-122

Esnault C, Nicolle JC (1976) Evolution de l'ADN et des protéines nucléaires basiques au cours de la maturation des cellules germinales du bélier. Etude microspectrophotométrique. Ann Histochem 21, 187-197

Evenson DP, Darzynkiewicz Z, Melamed MR (1980) Relation of mammalian sperm chromatin heterogeneity to fertility. Science 210 , 1131-1133

Gledhill BL (1971) Changes in deoxyribonucleoprotein in relation to spermateliosis and the epididymal maturation of spermatozoa. $J$ Reprod Fertil (suppl) 13, 77-88

Johnson LA (1985) Fertility results using frozen boar spermatozoa : 1970 to 1985. In: Deep Freezing of Boar Semen (Johnson LA, Larsson $\mathrm{K}$, eds), University of Agriculture Sciences, Uppsala, Sweden, 61-87

Kvist U, Kjellberg S, Bjorndahl L, Hammar M, Roomans GM (1988) Zinc in sperm chromatin and chromatin stability in fertile men and men in barren unions. Scand $J$ Urol Nephrol 22, 1-6

Lwoff L, Bézard J, Paquignon M (1987) Comparaison de technologies de conservation des spermatozoïdes de verrat: Effet sur les mécanismes de la fécondation. Journ Rech Porcine Fr 19, 79-86 
Mahadevan MM, Trounson AO (1984) Relationship of fine structure of head to fertility of frozen human semen. Fertil Steril 41, 287-293

Nicolle JC, Fournier-Delpech S, Courot M (1985) Influence of uterine secretions on the chromatin of ram spermatozoa at different stages of maturation: cytophotometric study of Feulgen-DNA after in vitro incubation. Gamete Res 11, 321-328

Oettle EE, Soley JT (1986) Ultrastructural changes in the acrosome of human sperm during freezing and thawing: a pilot trial. Arch Androl 17, 145-150

Paquignon M, Bussière J, Bariteau $F$, Courot M (1980) Effectiveness of frozen boar semen under pratical conditions of artificial insemination. Theriogenology 14, 217-226

Paquignon M (1984) Semen technology in the pig. Curr Top Vet Med Anim Sci 30, 202-218

Pedersen H, Lebech PE (1971) Ultrastructural changes in the acrosome of human sperm during freezing for artificial insemination. Fertil Steril 22, 125-133

Royère D, Hamamah S, Nicolle JC, Barthelemy C, Lansac $\mathrm{J}$ (1988) Freezing and thawing al- ter chromatin stability of ejaculated human spermatozoa : Fluorescence acridine orange staining and Feulgen-DNA cytophotometric studies. Gamete Res 21, 51-57

Schwartz D, Heuchel V (1982) Seminal factors of fertility in AID. In: Human Fertility Factors (Spira A, Jouannet $P$, eds), Inserm, Paris, 201-209

Schwartz D, Heuchel V, Mayaux MJ, O'quigley J (1983) Evaluation of early embryonic mortality in donor insemination by a mathematical model, globally and depending on semen quality. Gamete Res 8, 371-377

Siegel S (1956) Non Parametric Statistics for the Behavioral Sciences. McGraw-Hill, NY

Stockert JC, Lisanti JA (1972) Acridine orange differential fluorescence of fast and slowreassociation chromosomal DNA after in situ DNA denaturation and reassociation. Chromosoma (Berl) 37, 117-130

Tejada RI, Mitchell JC, Norman A, Marik JJ, Friedman $S$ (1984) A test for the practical evaluation of male fertility by acridine orange (AO) fluorescence. Fertil Steril 42, 87-91 